\title{
MET mutation and familial gastric cancer
}

\author{
J D Chen, S Kearns, T Porter, F M Richards, E R Maher, B T Teh
}

EDITOR-Approximately $10 \%$ of gastric cancers show familial clustering and case control studies have identified a threefold increased risk of the disease in the first degree relatives of affected subjects. ${ }^{1}$ Gastric cancer susceptibility is a well recognised feature of hereditary non-polyposis colorectal cancer syndrome and may be associated with familial polyposis coli, Peutz-Jeghers syndrome, and germline $p 53$ mutations. ${ }^{12}$ In addition, germline E-cadherin gene $(C D H 1)$ mutations cause familial diffuse gastric cancer. ${ }^{3-5}$ However, most familial gastric cancer patients do not have germline $C D H 1$ mutations. ${ }^{16}$ Very recently, Lee et al described a germline MET mutation (P1009S) in a patient with primary gastric cancer, although no detailed family history was available. In contrast with MET gene mutations in the tyrosine kinase domain, which are associated with hereditary type 1 papillary renal cell carcinoma and hepatocellular carcinoma, this mutation occurred in the juxtamembrane domain. The P1009S mutation was shown to be functionally tumorigenic and cause persistent tyrosine phosphorylation compared to the wild type $M E T^{7}$ This finding, together with the frequent somatic involvement of $M E T$ in gastric cancer, ${ }^{8}$ suggested that germline $M E T$ gene mutations might account for some of the gastric cancer families that are not associated with $\mathrm{CDH} 1$ mutations.

To investigate this hypothesis we examined probands from 18 kindreds with gastric cancer susceptibility: (1) 16 kindreds with two or more cases of gastric cancer (range 2-7); (2) one kindred with a single case of early onset gastric cancer (aged 38), a case of early onset breast cancer, and a case of early onset pancreatic cancer; and (3) one kindred with a case of early onset gastric cancer (aged 21), a case of early onset bile duct cancer, and a case of early onset pancreatic cancer. In eight of the 16 kindreds in group 1, there were also cases of early onset extragastric cancers, such as colorectal, breast, and throat. Detailed histopathology was available for six of these 18 kindreds: five had diffuse gastric cancer and one intestinal gastric cancer. In all 18 cases, $C D H 1$ mutation analysis by SSCP (as described previously by Richards $e t a{ }^{\tilde{}}$ ) had shown no evidence of germline CDH1 mutations.

\section{Methods}

To examine these patients for germline $M E T$ gene mutations within the juxtamembrane and tyrosine kinase domains, polymerase chain reaction (PCR) was carried out in exons 14 and 16 to 21 in a $50 \mu \mathrm{l}$ reaction volume containing $50 \mathrm{ng}$ DNA, $20 \mathrm{mmol} / \mathrm{l}$ Tris- $\mathrm{HCl}$ ( $\mathrm{pH} 8.4$ ), $50 \mathrm{mmol} / 1 \mathrm{KCl}, 1.5 \mathrm{mmol} / 1 \mathrm{MgCl}_{2}$, $0.2 \mu \mathrm{mol} / 1$ each primer, $0.2 \mathrm{mmol} / 1 \mathrm{dATP}$, dGTP, dCTP, dTTP each, and two units of Taq DNA polymerase (GIBCO-BRL, Life Technologies). Amplification was carried out in a programmable thermal cycler (GeneAmp PCR system 9700, Perkin-Elmer) at the following settings: after a denaturation at $94^{\circ} \mathrm{C}$ for five minutes, samples were amplified for 35 cycles at $94^{\circ} \mathrm{C}$ for 30 seconds, $55-58^{\circ} \mathrm{C}$ for 30 seconds, and $72^{\circ} \mathrm{C}$ for 45 seconds, with a final extension at $72^{\circ} \mathrm{C}$ for 10 minutes. After amplification, all the PCR products were subjected to purification using Microcon YM-100 column (Amicon, Millipore) and direct sequencing using ABI PRISM BigDye Terminator cycle sequencing ready reaction kit (PE Applied Biosystems).

\section{Results}

We did not find any MET mutation in the juxtamembrane or tyrosine kinase domains in a large series of familial gastric cancer cases, suggesting that $M E T$ gene mutations are an infrequent cause of gastric cancer susceptibility in the sample studied. To date, germline $C D H 1$ mutations have only been described in familial diffuse gastric cancer. The $M E T$ gene mutation (P1009S), reported by Lee et al, ${ }^{7}$ was found in a Korean patient with intestinal gastric cancer (J-H Lee, personal communication); it is possible that this mutation may be ethnic specific and not found in other populations (16 of our cases were white and two were from the Indian subcontinent). The mutation may also be specific to intestinal type of gastric cancer rather than the diffuse type, which was found in $5 / 6$ of our families in which the histology was available.

\section{Conclusion}

In conclusion, our findings suggest that further investigations are required to identify susceptibility genes that account for the majority of $E$-cadherin negative gastric cancer families. 
1 Caldas C, Carneiro F, Lynch HT, Yokota J, Wiesner GL Powell SM, Lewis FR, Huntsman DG, Pharoah PD, Jankowski JA, MacLeod P, Vogelsang H, Keller G, Park KG, Richards FM, Maher ER, Gayther SA, Oliveira C, Grehan N, Wight D, Seruca R, Roviello F, Ponder BA, Jackson CE. Familial gastric cancer: overview and guidelines for management. $\mathcal{F}$ Med Genet 1999;36:873-80.

2 Lynch HT, de la Chapelle A. Genetic susceptibility to nonpolyposis colorectal cancer. F Med Genet 1999;36:801-18.

3 Guilford P, Hopkins J, Harraway J, McLeod M, McLeod N, Harawira P, Taite H, Scoular R, Miller A, Reeve AE. E-cadherin germline mutations in familial gastric cancer. Nature 1998;392:402-5.

4 Gayther SA, Gorringe KL, Ramus SJ, Huntsman D, Roviello F, Grehan N, Machado JC, Pinto E, Seruca R, Halling $\mathrm{K}$, MacLeod P, Powell SM, Jackson CE, Ponder $\mathrm{BA}$, Caldas C. Identification of germ-line E-cadherin mutations in gastric cancer families of European origin. Cancer Res 1998;58:4086-9.

5 Cancer Res 1998;58:4086-9. DG, Jankowski JA, McKeown C, Sanders DS, Maher ER. Germline E-cadherin gene (CDH1) mutations predispose to familial gastric cancer and colorectal cancer. Hum Mol Genet 1999;8:607-10.

6 Avizienyte E, Launonen V, Salovaara R, Kiviluoto T, Aaltonen LA. E-cadherin is not frequently mutated in hereditary gastric cancer. F Med Genet 2001;38:49-51.

7 Lee JH, Han SU, Cho H, Jennings B, Gerrard B, Dean M, Schmidt L, Zbar B, Van de Woude GF. A novel germ line juxtamembrane Met mutation in human gastric cancer. Oncogene 2000;19:4947-53.

8 Nakajima M, Sawada H, Yamada Y, Watanabe A, Tatsumi M, Yamashita J, Matsuda M, Sakaguchi T, Hirao T, Nakano H. The prognostic significance of amplification and overexpression of c-met and c-erb B-2 in human gastric carcinomas. Cancer 1999;85:1894-902. 